\title{
TEMPERATŪROS ITAKA FOTOVOLTINEI JĖGAINEI
}

\author{
Modestas PIKUTIS \\ Vilniaus Gedimino technikos universitetas, Vilnius, Lietuva \\ El.paštasmodestas.pikutis@dok.vgtu.lt
}

\begin{abstract}
Santrauka. Fotovoltinėse jẻgainėse naudojami ̨̣vairaus tipo skirtingo veikimo efektyvumo saulès elementai. Nors šie elementai pagal tipą ir efektyvumą skirtingi, tačiau visiems jiems didelę įtaką daro aplinkos sąlygos. Pagrindinè priemonè fotovoltinės jègainès (FJ) efektyvumui didinti yra didžiausios galios taško sekimas (DGT). Dauguma valdiklių, skirtų didžiausios galios taškui sekti fotovoltinejje jègainèje, yra lèti arba netikslūs - negali palaikyti fotovoltinès jègainès didžiausios galios režimo. Tai pagrindiné fotovoltinès jẻgainès neefektyvaus veikimo priežastis. Fotovoltinių jëgainių tyrimams realiomis eksploatavimo sąlygomis ieškant efektyvesnių valdymo algoritmų būtinos didelès investicijos ị ịrangą, ir tai ilgai trunka. Tyrimams paspartinti kuriami imitaciniai modeliai. Šiame darbe aprašomas sukurtas temperatūros poveikiui tirti skirtas saulès modulio temperatūros kitimo blokas. Tai galimybė imituoti procesus, trunkančius mėnesị ar net kelerius metus. Darbe analizuojamą FJ modelị sudaro keturi struktūriniai blokai: saulès galios srautą imituojantis blokas, temperatūros kitimą imituojantis blokas, saulès modulių imitatorius ir valdymo algoritmas, kuriame didžiausios galios taškas nustatomas pagal IncCond algoritmą. Visas fotovoltinès jègainès modelis, ịgyvendintas Matlab/Simulink terpèje, leido analizuoti fotovoltinès jègainès veikimo efektyvumą giedrą dieną, kai moduliu temperatūra buvo pastovi arba kito.
\end{abstract}

Reikšminiai žodžiai: saulès elemento temperatūra, saulès elementai, didžiausios galios taško sekimas.

\section{Ivadas}

Rinkoje esama ịvairaus tipo saulès elementų: amorfinių, kurie yra labai pigūs ir kol kas mažiausiai efektyvūs; brangesnių - silicio monokristalinių, daug geresnių saulès energijos vertimo ị elektros energiją savybių, bei daugelis kitų (Chu, Meisen 2011).

Intensyviai ieškoma būdų pagerinti saulès elementų fizikines savybes. Daugumos elementų naudingumo koeficientas kol kas neviršija 20 \%. Kadangi saulès elementų naudingumo koeficientas nedidelis, ypač yra svarbu, kad jie visada veiktų jų galiai pasiekus aukščiausiajj tašką. Tokiam režimui palaikyti naudojami valdikliai. Valdikliai taiko skirtingus didžiausiosios galios taško sekimo algoritmus (Esram, Chapman 2007). Nuo valdymo algoritmo priklauso, kaip greitai bus aptiktas saulès modulio didžiausiosios galios taškas ir kaip tiksliai jis bus sekamas.

Fotovoltinès jëgainès DGT sekimą apsunkina neprognozuojamai kintančios aplinkos sąlygos ir įvairių saulès elementų ar modulių itin skirtingos veikimo charakteristikos. Šių pavienių saulès elementų ar saulès modulių skirtumų gali atsirasti, kai dalis fotovoltinès jègainès dèl išorinių veiksnių patenka i šešèlị, padengiama sniego, šerkšno, dulkių ar tiesiog ant kai kurių saulès elementų prilimpa nukritę medžio lapai. Šie veiksniai yra ypatingi tuo, kad jų negalima numatyti iš anksto, be to, šios sąlygos niekada identiškai neatsikartoja. Dėl šių priežasčių nèra galimybès iš anksto numatyti fotovoltinès jègainès apkrovos tam tikrais laiko intervalais.

Tinkamai parinkti saulès modulio apkrovą yra itin svarbu, nes tik tada pasiekiamas jègainès veikimo didžiausiosios galios taškas, kai ji geba maksimaliai panaudoti krintantị saulès galios srautą (SGS).

Didžiausiosios galios taškas saulès elemente, esant skirtingoms jo temperatūroms, gali kisti (Buday 2011). Ankstesnių tyrimų metu buvo atliekami ịvairūs bandymai laikant, kad modulio temperatūra yra nekintanti ir lygi $25^{\circ} \mathrm{C}$ (Vasarevičius et al. 2012). Buvo tiriamas fotovoltinès jègainès algoritmo veikimas atsižvelgiant tik ị saulès galios srauto kitimą. Tačiau norint tiksliai ištirti ir įvertinti fotovoltinès jègainès veikimą tokiomis aplinkos sąlygomis, kurios artimos realioms, būtina ịvertinti modulio temperatūros kitimą (Siddiqui, Bajpai 2012).

Tirti fotovoltinès jëgainès veikimą realiomis aplinkos sąlygomis itin brangu ir sudètinga, procesas ilgai trunka. To galima išvengti tyrimų metu imituojant realias darbo sąlygas sudarytame matematiniame fotovoltinès jègainès modelyje. Nesudétingai galima palyginti saulès jègainès 
veikimą atitinkamais laiko momentais, kai keičiami tik norimi parametrai.

Darbe siekiama ištirti temperatūros įtaką pavieniam saulès moduliui bei visos fotovoltinès jègainès valdymui. Tikslui igyvendinti naudojamas ankstesniuose tyrimuose sukurtas Matlab/Simulink modelis (Pikutis et al. 2014), papildytas bloku, imituojančiu modulio temperatūros pokyčius atitinkamu laiko momentu.

\section{Temperatūros įtaka saulès moduliui}

Žinoma (Vasarevičius et al. 2012), kad jègainès valdiklis jautriai reaguoja i greitus saulès galios srauto pokyčius. Tačiau nèra žinoma, kaip valdiklis veikia, kai vienu metu keičiasi du pagrindiniai veiksniai, turintys ịtakos jo veikimui - pakinta SGS ir modulio temperatūra. Jègainès veikimas tiriamas tokiu nuoseklumu: pirmiausia tiriamas aplinkos poveikis pavieniam saulès moduliui, vèliau - iš trijų saulès modulių (SM) sudarytai jègainei.

Tyrimo metu buvo imituojama, kad ị saulès moduli patenka skirtingas saulès galios srautas, kai modulio temperatūra yra $25{ }^{\circ} \mathrm{C}$ ir kai ji padideja iki $50{ }^{\circ} \mathrm{C}$. Gautos voltamperinès charakteristikos pateiktos 1 pav. Jose tašku pažymètas didžiausiosios galios taškas. Pirmoji kreivė apibūdina didžiausiosios galios tašką, kai modulio temperatūra $25{ }^{\circ} \mathrm{C}$ ir ị jị patenka $1000 \mathrm{~W} / \mathrm{m}^{2}$ saulès galios srautas. Antroji kreivè atvaizduoja modulio DGT, kai i ji krinta $600 \mathrm{~W} / \mathrm{m}^{2}$ saulès galios srautas esant tokiai pat $25^{\circ} \mathrm{C}$ temperatūrai. Trečioji kreivè atvaizduoja DGT, kai saulès galios srautas tik $400 \mathrm{~W} / \mathrm{m}^{2}$, o temperatūra išlikusi $25^{\circ} \mathrm{C}$. Šiose kreivėse nustatytas didžiausiosios galios veikimo taškas nusako modulio veikimą esant skirtingam apšviestumui ir tai pačiai temperatūrai. Ketvirtoji kreivė atvaizduoja modulio veikimą, kai i jị patenka $600 \mathrm{~W} / \mathrm{m}^{2}$ saulès galios srautas ir pakinta tik modulio temperatūra - pakyla iki $50{ }^{\circ} \mathrm{C}$. Penktoji kreivè apibūdina dviejų faktorių poveikị

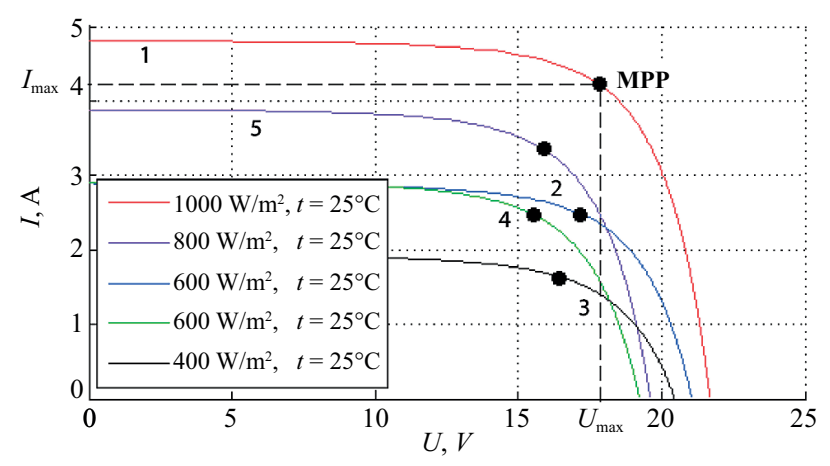

1 pav. DGT esant skirtingiems saulès galios srautams ir temperatūroms

Fig. 1. MPP depending on a different solar radiation and temperature saulès modulio veikimui - saulès galios srautas padideja nuo $600 \mathrm{~W} / \mathrm{m}^{2}$ iki $800 \mathrm{~W} / \mathrm{m}^{2}$, o modulio temperatūra pakyla nuo $25^{\circ} \mathrm{C}$ iki $50{ }^{\circ} \mathrm{C}$.

Lyginant pirmą, antrą ir trečią kreives matyti, kad esant vienodai modulio temperatūrai ir mažèjant tik saulès galios srautui, žymiai krinta modulio srovè. SGS sumažèjus nuo $1000 \mathrm{~W} / \mathrm{m}^{2}$ iki $600 \mathrm{~W} / \mathrm{m}^{2}$ (žr. kreives 1 ir 2) srovè sumažèja $1,9 \mathrm{~A}$ - tai $45 \%$ pokytis. Ittampos pokytis mažesnis - įtampa sumažèja vos 1,1 V (apie $6 \%$ ). Šiuo atveju galia sumažèja 32,7 W. Kai modulio temperatūra siekia $50{ }^{\circ} \mathrm{C}$, o SGS sumažèja nuo $800 \mathrm{~W} / \mathrm{m}^{2}$ iki $600 \mathrm{~W} / \mathrm{m}^{2}$ (žr. kreives 4 ir 5) - srovè sumažèja 0,97 A, o įtampa pakinta vos 0,6 V. Galia sumažèja 14,2 W. Kai saulès galios srautas nekinta ir yra lygus $600 \mathrm{~W} / \mathrm{m}^{2}$, o temperatūra pakyla nuo $25^{\circ} \mathrm{C}$ iki $50{ }^{\circ} \mathrm{C}$ (žr. kreives 2 ir 4), srovė beveik nepakinta, tačiau modulio ịtampa sumažèja net 2,3 V, dèl to $9 \mathrm{~W}$ sumažèja galia.

Iš 2 ir 4 kreivès matyti, kad esant $600 \mathrm{~W} / \mathrm{m}^{2} \mathrm{SGS}$ modulio momentinè galia yra didesnè, kai jo temperatūra yra žemesnè. Atlikti išsamesni tyrimai didinant modulio temperatūrą patvirtino, kad didejjant modulio temperatūrai jo gaminama galia, esant tokiam pačiam saulès galios srautui, dar daugiau sumažeja. Taigi galima teigti, kad optimizuojant fotovoltinès jègainès veikimą būtina įvertinti modulio charakteristikų priklausomybę ne tik nuo saulès galios srauto, bet ir nuo modulio temperatūros.

\section{Modelio struktūrinė schema}

2 pav. pateikta matematinio modelio struktūrinè schema temperatūros ịtakai fotovoltinès jẻgainès veikimui ištirti. Čia saulès jègainę sudaro trys nuosekliai sujungti saulès moduliai. Kiekvieną SM sudaro 36 saulès elementai, kurių bendra galia esant standartinèms testavimo sąlygoms lygi $150 \mathrm{~W}$. Taigi bendra jègainès galia siekia $450 \mathrm{~W}$. I kiekvieną saulès modulį siunčiamas vienodą saulès galios srautą imituojantis signalas $S_{\mathrm{T}}$. Šị signalą generuoja SGS blokas. Bloko parametrai parinkti taip, kad jo generuojamas signalas imituotų SGS Lietuvos sąlygomis. Tam, kad modelis imituotų fotovoltinės jëgainės veikimą kintančioje aplinkos temperatūroje, papildomai sudaromas ir prijungiamas saulès modulio temperatūros kitimo blokas. Kadangi laikoma, kad visi modelio saulès moduliai yra to paties tipo ir juos veikia vienodos aplinkos sąlygos, tas pats temperatūros kitimo signalas siunčiamas ị visus FJ modulius. Taigi šie blokai imituoja SGS ir modulių ǐšilimo signalus atitinkamu laiko momentu.

Saulès moduliai, veikiami saulès galios ir temperatūros signalų, generuoja ịtampą $U_{\mathrm{FVM}}$ ir kuria srovę $I_{\mathrm{FVM}}$, kuri teka per apkrovą. Didžiausiosios galios taško sekimą 


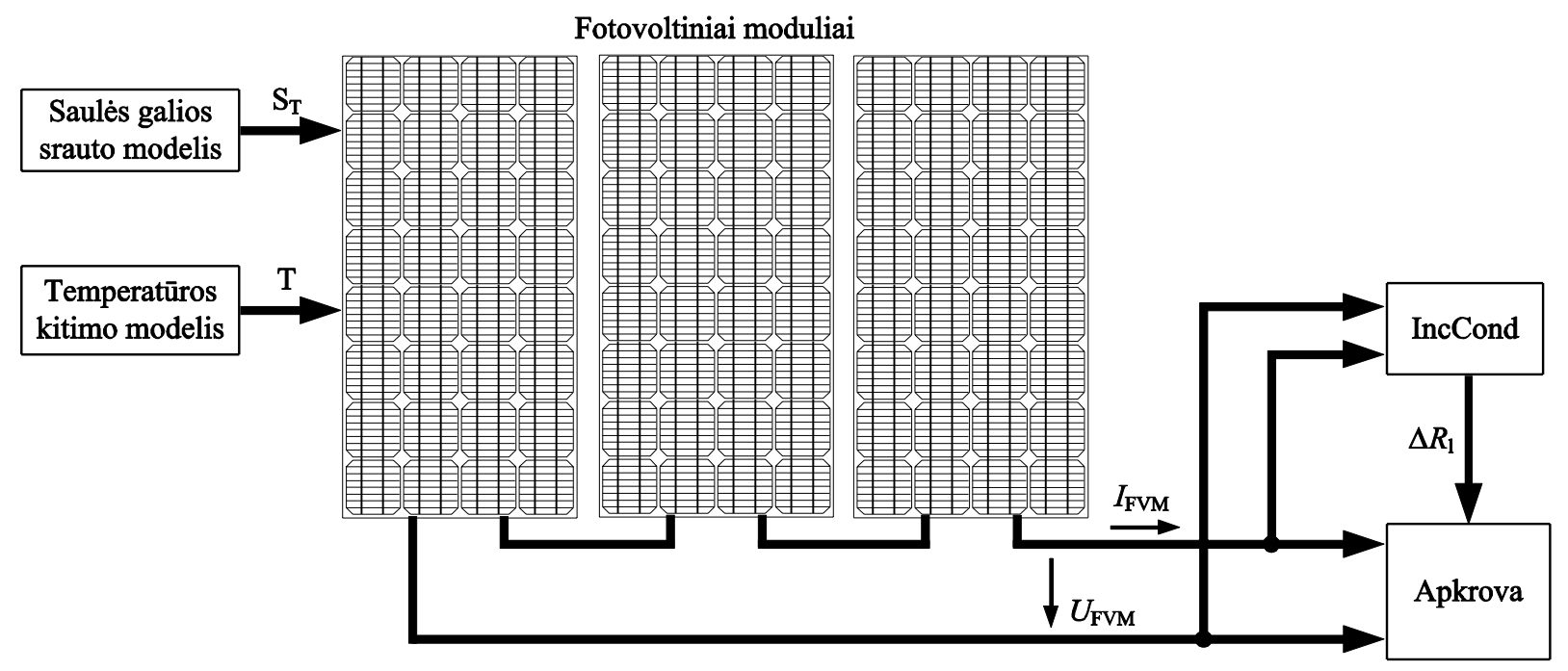

2 pav. Matematinio modelio struktūrinè schema

Fig. 2. Structural diagram of a mathematical model

jëgainèje atlieka IncCond algoritmas (Zegaoui et al. 2010) lyginamos fotovoltinès jëgainès išmatuotos trumpojo jungimo srovẽs $I_{\text {tr }}$ ir tuščiosios veikos ịtampos $U_{\text {at }}$ vertès su prieš tai buvusiomis, atitinkamai reguliuojama jègainès apkrova, ji padidinama arba sumažinama žingsniu $\Delta \mathrm{R}$.

\section{Matematinis fotovoltinės jẻgainès modelis}

Saulès modulio temperatūros kitimo ịtakai fotovoltinèje jègainèje ištirti sudarytas matematinis fotovoltinès jègainès modelis pateiktas 3 pav. Remiantis struktūrine schema (2 pav.), modelis igyvendintas Matlab/Simulink terpeje. Modelị sudaro saulès galios srautą imituojantis SGS blokas. Generuojamam signalui priartinti prie realių sąlygų naudojami papildomi ịvesties blokai: pasvirimo kampas, albedas, metų diena, geografinè platuma, paros laikas, aukštis virš jūros lygio, geografinè ilguma, laiko juosta. Keičiant šiuos parametrus, generuojamas signalas, imituo- jantis saulės galios srautą, patenkantị ị skirtingas žemės paviršiaus vietas atitinkamu laiko momentu.

Temperatūros ịtaka fotovoltinès jègainès valdymui imituojama laikant, kad diena yra giedra ir be kritulių.

Modelyje generuojamas SGS signalas imituoja saulès patekèjimą 6:00 val., o nusileidimą - 20:00 val. Taigi didžiausiosios galios taškas jègainèje sekamas visą 14 val. trunkantị šviesujji paros laiką. Saulès galios srauto bloke generuojamas signalas siunčiamas ị Gauso filtrą, iš kurio patenka ị kiekvieną saulès moduli.

Modulio temperatūrą jẻgainès modelyje nustato temperatūros blokas, kurio generuojamas tolygus saulès patekejjimą ir nusileidimą imituojantis signalas siunčiamas ì kiekvieną jègainès saulès modulị. Temperatūros blokas sudarytas taip, kad pagal saulès galios srauto intensyvumą kistų modulio temperatūra. Kadangi tyrimo metu siekiama ištirti temperatūros įtaką fotovoltinei jègainei, imituojama, kad saulès galios srautas kinta tolygiai. Šiuo atveju jam

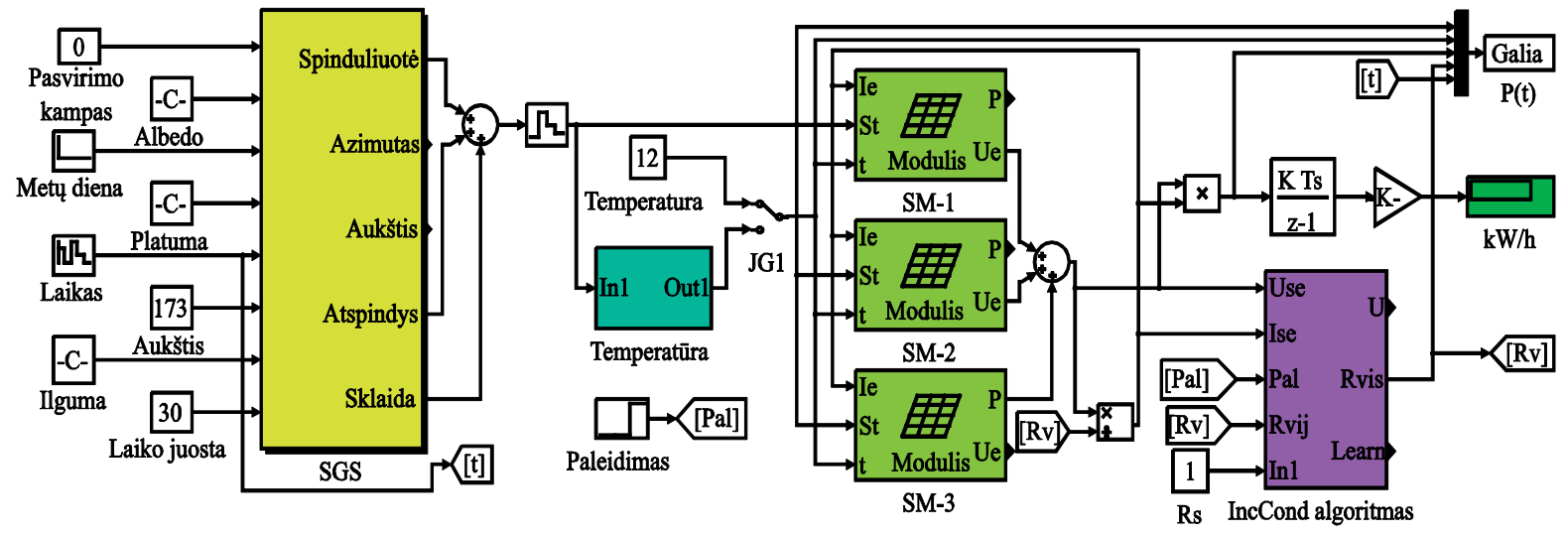

3 pav. Matlab/Simulink modelis, atspindintis temperatūros kitimą

Fig. 3. Matlab/Simulink model with temperature block 
neturi įtakos šalutiniai veiksniai - vejjas, debesys ir nenumatytai susidarantys šešèliai. Modelyje imituojama, kad kiekvienas saulès modulis, reaguodamas į SGS atitinkamu laiko momentu, ǐšla ar pradeda vèsti.

Fotovoltinèje jègainèje moduliai yra sujungti nuosekliai, todẻl išejime jų ịtampa yra sumuojama. Gauta įtampos verte siunčiama ị IncCond algoritmo bloke įdiegtą didžiausiosios galios taško sekimo valdiklį.

\section{Temperatūros įtaka fotovoltinės jègainės našumui}

Tyrimo metu pavieniais bandymais imituotos ivairios aplinkos sąlygos. Pirmasis bandymas buvo imituojant, kad fotovoltinè jègainè veikia, kai modulių temperatūra nekinta ir atitinka standartinę $25^{\circ} \mathrm{C}$ testavimo sąlygų temperatūrą (4 pav., 2 kreivè). 4 pav. 1 kreivė žymi tolygų saulès galios srauto kitimą nuo 0 iki $900 \mathrm{~W} / \mathrm{m}^{2}$ šviesiuoju paros laiku. 3 kreivè atvaizduoja apskaičiuotą momentinę galią, kurią generuoja valdiklio valdoma fotovoltinè jègainè.

Iš galios charakteristikos, atvaizduotos 4 pav. 3 kreive, matyti, kad, saulès galios srautui tolygiai kintant ir esant pastoviajai $25^{\circ} \mathrm{C}$ temperatūrai, valdiklis be nukrypimų geba sekti DGT. Šiomis sąlygomis fotovoltinè jègainè pagamina $3023 \mathrm{Wh}$ elektros energijos.

5 pav. pateikti antrojo bandymo rezultatai. Imituojamas fotovoltinès jègainès veikimas nekintamoje $12{ }^{\circ} \mathrm{C}$ modulių temperatūroje (2 kreivè). Šiame paveiksle saulès galios srauto kitimą žymi 1 kreivè. Ji yra tokia pati kaip ir pirmojo bandymo metu. 3 kreive 5 pav. vaizduoja fotovoltinès jẻgainès generuojamą momentinę galią. Taigi esant

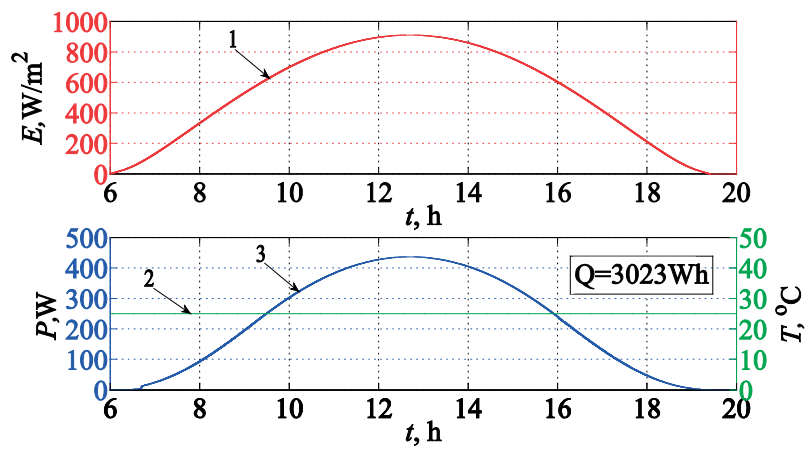

4 pav. Charakteristikos, apibūdinančios fotovoltinès jẻgainès veikimą giedrą dieną, kai modulių temperatūra nekinta ir lygi $25{ }^{\circ} \mathrm{C}: 1$ - saulès galios srauto $S_{\mathrm{T}}$ kitimo šviesiuoju paros metu kreivé; 2 - moduliu temperatūra veikiant fotovoltinei jègainei; 3 - momentinè fotovoltinès jègainès galia atitinkamu laiko momentu

Fig. 4. Solar power plant working characteristic on a bright day, when photovoltaic module temperature is constant and $25^{\circ} \mathrm{C}: 1$ - curve of solar irradiance $S_{\mathrm{T}} ; 2$ - curve of photovoltaic module temperature; 3 - power at the output of solar power plant

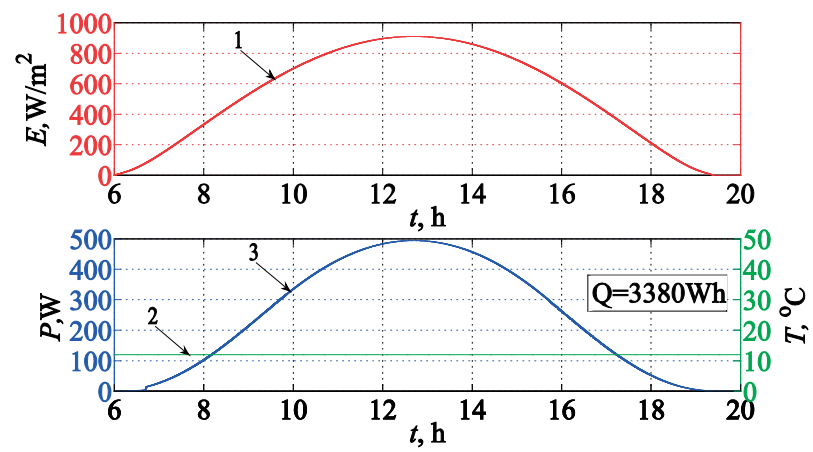

5 pav. Charakteristikos, apibūdinančios fotovoltinès jègainès veikimą giedrą dieną, kai modulių temperatūra nekinta ir lygi $12{ }^{\circ} \mathrm{C}$ : 1 - saulès galios srauto $S_{\mathrm{T}}$ kitimo šviesiuoju paros metu kreivè; 2 - modulių temperatūra fotovoltinès jègainès veikimo metu; 3 - momentinè fotovoltinès jègainès galia atitinkamu laiko momentu

Fig. 5. Solar power plant working characteristic on a bright day, when photovoltaic module temperature is constant and $12{ }^{\circ} \mathrm{C}$ : 1 - curve of solar irradiance $S_{\mathrm{T}} ; 2$ - curve of photovoltaic module temperature; 3 - power at the output of solar power plant

tokiam pačiam saulès galios srautui kaip ir pirmojo bandymo metu, jẻgainè pagamina $3380 \mathrm{Wh}$ elektros energijos.

Lyginant 4 ir 5 pav. galios charakteristikas matyti, kad fotovoltinè jègainè daugiau elektros energijos pagamina, kai modulių temperatūra yra žemesnè. Matyti, kad kai modulių temperatūra žemesnè nei $13{ }^{\circ} \mathrm{C}$, jègainè gali pagaminti $357 \mathrm{Wh}$ elektros energijos daugiau. Taigi rekomenduojama esant galimybei saulès modulius aušinti.

Paskutinio, trečiojo, bandymo metu imituojama, kad modulių temperatūra tolygiai kinta. Tai būdinga giedrai dienai - intensyvèjant SGS didèja modulio temperatūra. 6 pav. 1 kreivé atvaizduoja SGS kitimą tokiu pat dèsningumu kaip ir ankstesniuose bandymuose. Šiame paveiksle 2 kreivè žymi modulių temperatūros kitimą, atsižvelgiant i saulès galios srauto intensyvumą. 3 kreivè atvaizduoja apskaičiuotą momentinę jẻgainès galią esant atitinkamoms aplinkos sąlygoms laiko momentu $t$.

Apskaičiuota, kad fotovoltinè jègainè per 14 val. pagamino 2824 Wh elektros energijos. Tai yra $199 \mathrm{Wh}$ mažiau nei tada, kai modulių temperatūra pastovi ir lygi $25{ }^{\circ} \mathrm{C}$, ir net $556 \mathrm{Wh}$ mažiau, kai modulių temperatūra visą fotovoltinès jègainès veikimo laiką buvo lygi $12{ }^{\circ} \mathrm{C}$.

Visų bandymų metu FJ valdiklis gebejjo aptikti didžiausios galios tašką ir ji sekti. Galima teigti, kad tolygus modulių temperatūros kitimas neturi įtakos fotovoltinès jègainès valdymo algoritmui, tačiau turi didelę ịtaką modulių efektyvumui. 


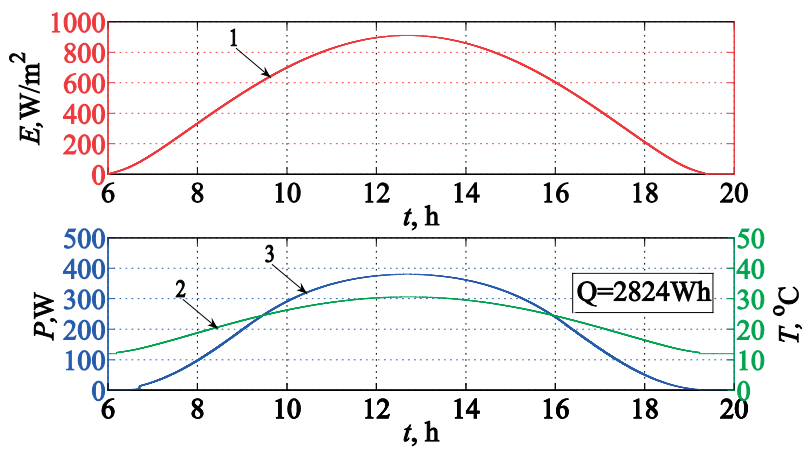

6 pav. Charakteristikos, apibūdinančios fotovoltinès jègainès veikimą giedrą dieną, kai modulių temperatūra kinta priklausomai nuo saulès galios srauto intensyvumo: 1 - saulès galios srauto $S_{\mathrm{T}}$ kitimo šviesiuoju paros metu kreivė; 2 - modulių temperatūra fotovoltinès jègainès veikimo metu; 3 - momentinè fotovoltinès jègainès galia atitinkamu laiko momentu

Fig. 6. Solar power plant working characteristic on a bright day, when photovoltaic module temperature is changing depending on solar irradiance: 1 - curve of solar irradiance $S_{\mathrm{T}}$; 2 - curve of photovoltaic module temperature; 3 - power at the output of solar power plant

\section{Išvados}

1. Pavienio saulès elemento gaminamai elektros energijai turi įtakos ne tik saulès galios srautas, bet ir jo temperatūra. Esant didesnei temperatūrai, saulès elemento efektyvumas mažèja.

2. Saulès modulių temperatūrai pakilus nuo $12{ }^{\circ} \mathrm{C}$ iki $25^{\circ} \mathrm{C}$ jègainè pagamina $10,6 \%$ mažiau elektros energijos nei gamintų esant pastoviai $12{ }^{\circ} \mathrm{C}$ temperatūrai.

3. Fotovoltinès jëgainès valdymo algoritmui tolygus modulių temperatūros kitimas, kai diena giedra, reikšmingos ịtakos neturi.

\section{Literatūra}

Buday, M. S. 2011. Measuring irradiance, temperature and angle of incidence effects on photovoltaic modules in Auburn Hills, Michigan: Thesis for the degree of master of science [interaktyvus]. Michigan: University of Michigan. 62 p. [žiūrèta 2014 m. spalio 27 d.]. Preiga per internetą: http://hdl.handle.net/2027.42/86065

Chu, Y.; Meisen, P. 2011. Review and comparison of different solar energy technologies [interaktyvus]. Global Energy Network Institute (GENI). 52 p. [žiūrèta 2015 m. kovo 5 d.]. Prieiga per internetą:

http://www.geni.org/globalenergy/research/review-and-comparison-of-solar-technologies/Review-and-Comparison-ofDifferent-Solar-Technologies.pdf

Esram, T.; Chapman, P. L. 2007. Comparison of photovoltaic array maximum power point tracking techniques, IEEE Transactions on Energy Conversion 22(2): 439-449. http://dx.doi.org/10.1109/TEC.2006.874230
Pikutis, M.; Vasarevičius, D.; Martavičius, R. 2014. Maximum power point tracking in solar power plants under partially shaded condition, Elektronika ir elektrotechnika 20(4): 49-52. http://dx.doi.org/10.5755/j01.eee.20.4.6677

Siddiqui, R.; Bajpai, U. 2012. Deviation in the performance of solar module under climatic parameter as ambient temperature and wind velocity in composite climate, International Journal of Renewable Energy Research 2(3): 486-490. http://www.ijrer.org/ijrer/index.php/ijrer/article/view/277/0

Vasarevičius, D.; Martavičius, R.; Pikutis, M. 2012. Application of artificial neural networks for maximum power point tracking of photovoltaic panels, Elektronika ir elektrotechnika 18(10): 65-68.

http://dx.doi.org/10.5755/j01.eee.18.10.3065

Zegaoui, A.; Petit, P.; Sawicki, J. P.; Charles, J. P.; Aillerie, M.; DellaKrachai, M.; Belarbi, A. O. 2010. Simulation of photovoltaic generators and comparison of two common maximum power point trackers, Renewable Energies and Power Quality Journal 8 [interaktyvus], [žiūrèta 2015 m. kovo 5 d.]. Prieiga per internetą: http://www.icrepq.com/icrepq'10/533-Zegaoui.pdf

\section{TEMPERATURE EFFECT TO SOLAR POWER PLANT}

\section{Pikutis}

\section{Abstract}

There are a lot of different efficiency photovoltaic cells, which are used in solar power plants. All of these different photovoltaic cells are affected by different environment conditions. Maximum power point tracking is the main way to increase solar power plant efficiency. Mostly systems of maximum power point tracking are slow or inaccurate, that means the system cannot stay in maximum power point in solar power plant. This is the main reason why mostly of solar power plants are working not efficiently. The use of real working solar power plant with aim to find more efficient control algorithms is very expensive and requires long development period. Mathematical modeling makes research and investigation faster. In this article a temperature changing block of photovoltaic module that can simulate temperature changing process for month or even a few years was proposed. This temperature block was used in a solar power plant model which was created in previous investigations. Now, solar power plant model has four structural blocks: solar irradiance block, temperature of photovoltaic module block, photovoltaic module block and controller block. IncCond algorithm is used for maximum power point tracking. Solar power plant model is implemented in Matlab/Simulink environment. This model enables to analyze solar power plant working efficiency, when there are no clouds and the temperature is changing or stays constant.

Keywords: temperature of solar cell, solar cells, maximum power point tracking. 